\title{
CURRENT STATE OF CRM SYSTEMS IN CONSTRUCTION
} INDUSTRY IN SLOVAKIA

\author{
Peter Mesároš \\ Technical University of Košice, Faculty of Civil Engineering, Department of Construction Technology and \\ Management, Vysokoškolská 4, 04200 Košice, Slovakia, EU, peter.mesaros@ tuke.sk (corresponding author)

\section{Tomáš Mandičák} \\ Technical University of Košice, Faculty of Civil Engineering, Department of Construction Technology and \\ Management, Vysokoškolská 4, 04200 Košice, Slovakia, EU, tomas.mandicak@tuke.sk

\section{Katarína Krajníková} \\ Technical University of Košice, Faculty of Civil Engineering, Department of Applied Mathematics, Vysokoškolská 4, \\ 04200 Košice, Slovakia, EU, katarina.krajnikova@tuke.sk

\section{Annamária Behúnová} \\ Technical University of Košice, Faculty of Manufacturing Technologies with a seat in Prešov, Bayerova 1, 08001 \\ Prešov, Slovakia, EU, annamaria.behunova@tuke.sk \\ Keywords: Customer Relationship Management, information systems, construction industry, Slovakia \\ Abstract: Customer relationship management systems are an important technology for resource efficiency in the \\ management of relations with customers. The use of customer relationship management systems is essential for high level \\ of customer retention. This paper discusses issue of usage rate of customer relationship management systems in \\ construction industry in Slovakia. Main aim of research was to analyse current state of usage rate of customer relationship \\ management systems between participants of construction project in Slovakia. Research sample includes developers, \\ designers, contractors and sub-contractor from Slovakia. It was divided according to size of company and length of time \\ on the market. Based on this, it were set assumption that company size has impact on use of CRM systems. Another \\ assumption was that length of time on the market has impact on use of CRM systems in Slovak construction industry.
}

\section{Introduction}

Order management or customer relationship management is one of the key issues for good business results [1]. Effective order management and customer relationships require a lot of information [2]. This, on the other hand, requires an information processing system. Precisely for these needs arise so-called customer relationship management systems (CRM). This narrowly specified area of information systems is relatively often used in large corporations abroad. The construction industry has specific features and therefore the usage rate does not have to correspond with other types of industries. This is particularly true in the context of the current situation in the Slovak construction industry. Based on research and studies already conducted, trends in the use of information systems have been outlined [3,4]. This is at a lower level compared to foreign enterprises in the construction sector. For this reason, it is very important to investigate these technologies and their utilization rate in the Slovak construction industry.

\subsection{Customer Relationship Management}

CRM or Customer Relationship Management is a strategy whose main goal is to better understand customers to meet their needs effectively and maximize their satisfaction. Customer information and knowledge are the means to achieve the greatest possible satisfaction. This information is acquired by the company through information and communication technology (ICT). In fact, with the increasing emphasis on e-business applications, CRM has become a major component of e-business strategy [5]. CRM systems are programs that allow you to collect, sort, and processing the customer data. In particular, they are collecting their contacts, information on ongoing business processes, and information on revenue and size. CRM systems help track and evaluate all business activities throughout the company. For this reason, CRM systems also include different statistical data as a result of the collection, sorting and evaluation of the information. CRM systems are based on a technology tool for managing and developing customer knowledge, through which the company strives to create superior customer relationships. The CRM system is thus an indispensable part of a global CRM strategy that emphasizes customer value creation. Thus, the company strengthens customer relationships, defines key customers, segmenting the market on which it operates, and differentiating between its campaign [6].

Customer relationship management is a set of processes, strategies and metrics, technology solutions that enhance organizations' ability to see differences between their customers. These systems also enable them to track new opportunities and immediately respond to customer needs [7]. According to another authors [8], the CRM system represents a link between customer-oriented 
strategy, marketing strategy, and initiatives combined with ICT tools. The primary purpose of these activities is to increase customer loyalty and satisfaction. This leads to increased sales of products resulting in increased sales. From these definitions, it follows that CRM is a system whose individual pages are closely related. CRM systems can not only be considered software solutions. However, software and technology solutions are a major part of the CRM system and act as a tool for implementing the core customer relationship management strategy. Thanks to these applications, the company can collect, analyse the necessary information that leads to important decisions of the company's marketing strategy.

The CRM system cannot be perceived merely as a software or technological solution. Many sources point to other views on CRM. Their difference is precisely from the functions and activities of stakeholders (participants). One is a management view that is geared to monitoring, research and output as such, regardless of the usage technique. There is also a view of business owners who are focused on concrete results without having to know their customers. Last but not least, this is a typical view from the point of view of software functionality, where software and technology itself is the focus [9].

In general, CRM can be viewed as:

- A marketing perspective - a specific marketing policy for a company practiced by a variety of tools, uses trends and methods of modern promotion, a strategy that is often part of its vision;

- IT (Information Technology) perspective - this is a technological, hardware and software solution, especially in terms of functionality, user environment, information flows and overall functionality as a system or part of the information system of the company.

From the marketing point of view, it is mainly about marketing activities connected with the effort to achieve customer loyalty, which results in great benefits for the company. For this reason, it is possible to talk about CRM as a strategy or a company's policy to coordinate processes and activities that are customer-oriented. According to one of the most prominent authors of marketing definitions, CRM represents the whole process of building a customer relationship. It deals with all aspects of acquiring, maintaining and building customer relationships that are of great value to the enterprise [10].

\section{Methodology}

\subsection{Data collection and research sample}

Data collection was realised by on-line questionnaire. All participants of construction project created a research sample. Especially, there were contractor, sub-contractor, designers and investors in Slovak construction market. The first, companies were divided into two categories,. First group includes SMEs (Small and medium sized enterprises) that means smaller (less than 49 employees). Next group includes large enterprises or bigger (50 and more employees). This is not a standard enterprise divided by size. However, given the research methods and statistical tests conducted during the research, they indicated the appropriateness of this divided. The second fact is that in Slovakia there are few large companies. With regard to the research sample, there would be great disparity in this breakdown and could lead to general conclusions that would not be supported by a sufficient research sample (because of size of sample $n=55$ ).

Secondly, research sample was divided according to length of time on the market. First group was set as new companies (from 0 to 10 years old). Second group was created by companies with length of time on the market between 11 and 20 years. Last group was from 21 and more years length of time on the market.

\subsection{Problem statement, hypotheses and Data processing}

The influence of company size on CRM systems using was desired. This hypothesis was established: Bigger companies desire CRM systems more useful than smaller companies. On the beginning, it was used very common test called Shapiro-Wilk test. It is test to determine if the null hypothesis of normality is a reasonable assumption regarding the population distribution of a random sample. The desired significance level alpha was used 5\% in all statistical tests. Computation of this test was done in Matlab (Table 1).

\begin{tabular}{|c|c|c|}
\multicolumn{1}{c}{} & Table 1 Descriptive statistics and normality \\
\cline { 2 - 3 } \multicolumn{1}{c|}{} & Smaller companies & Bigger companies \\
\hline Mean & $\mathbf{1 . 9 4 4 4}$ & $\mathbf{2 . 5 7 8 9}$ \\
\hline Variance & $\mathbf{1 . 1 9 6 8}$ & $\mathbf{2 . 1 4 6 2}$ \\
\hline $\begin{array}{c}\text { Number of } \\
\text { respondents }\end{array}$ & $\mathbf{3 6}$ & $\mathbf{1 9}$ \\
\hline Skewness & $\mathbf{1 . 2 2 4 3}$ & $\mathbf{0 . 4 7 8 2}$ \\
\hline Kurtosis & $\mathbf{1 . 3 8 9 5}$ & $\mathbf{- 1 . 0 6 1 3}$ \\
\hline p value & $<\mathbf{0 . 0 0 0 1}$ & $\mathbf{0 . 0 1 3}$ \\
\hline
\end{tabular}

The null hypothesis was rejected, so samples was not normally distributed. It was also done F-test Two-Sample for Variances to compare whether obtained variances were equal or not. We found out $(\mathrm{p}=0.068)$ that our samples variances were equal. Therefore these results, the MannWhitney test (non-parametric alternative to t-test) was used to check our hypothesis about useful CRM systems for both cases. Firstly for assumption about company size and second assumption for length of time on the market.

For second scope of research, it was use other tests. These groups were not normally distributed because their p-values were $0.0025,0.0244,<0.001$, respectively. It was used Kruskal-Wallis test. 


\section{Results and discussion}

First point of view, it was influence of company size on CRM system using in Slovak construction industry. It was assumption that bigger companies use CRM system more than smaller enterprises. It was done Mann-Whitney U test for this purpose (Table 2). Exactly, the mean ranks of two groups of companies were tested. The desired hypotheses:

H0: The mean ranks of two groups are equal.

H1: The mean ranks of two groups are not equal.

Table 2 The results of Mann-Whitney U test

\begin{tabular}{|c|c|c|}
\cline { 2 - 3 } \multicolumn{1}{c|}{} & Smaller companies & Bigger companies \\
\hline $\begin{array}{c}\text { Sum of } \\
\text { ranks }\end{array}$ & $\mathbf{9 2 5}$ & $\mathbf{6 1 5}$ \\
\hline $\begin{array}{c}\text { Mean of } \\
\text { ranks }\end{array}$ & $\mathbf{2 5 . 6 9}$ & $\mathbf{3 2 . 3 7}$ \\
\hline $\begin{array}{c}\text { Expected } \\
\text { sum of } \\
\text { ranks }\end{array}$ & $\mathbf{1 0 0 8}$ & $\mathbf{5 3 2}$ \\
\hline U-value & $\mathbf{4 2 5}$ & $\mathbf{2 5 9}$ \\
\hline Z-score & $\mathbf{- 1 . 4 6 0 2}$ & \\
\hline p value & $\mathbf{0 . 1 4 4 3}$ & \\
\hline $\begin{array}{c}\text { Expected } \\
\text { U-value }\end{array}$ & $\mathbf{3 4 2}$ & \\
\hline
\end{tabular}

The gained results were not significant at significance level alpha, $\mathrm{H} 0$ was not rejected and it could be considered that means of samples were equal. So, bigger companies desire CRM systems equally useful than smaller companies. Based on this, general assumption about company size influence was not confirm. These results are interesting. This may have several reasons. Numbers of large companies in Slovak market can be a reason. One of them, it can be very small representation of large companies in Slovak construction market. Such is the Slovak construction market. This can also affect statistics. Perhaps if similar research was carried out in Poland where there are several large companies on the market, the results would be different. The reason could not be the fact that in Poland the systems are used to a greater extent, but the fact that, if there are more companies, there is a bigger prerequisite for the use of these systems as well.

The second, some dependence between length of time on the market and using CRM systems was investigated. The companies were divided into three groups according by length of time on the market (in years) (Figure 1).

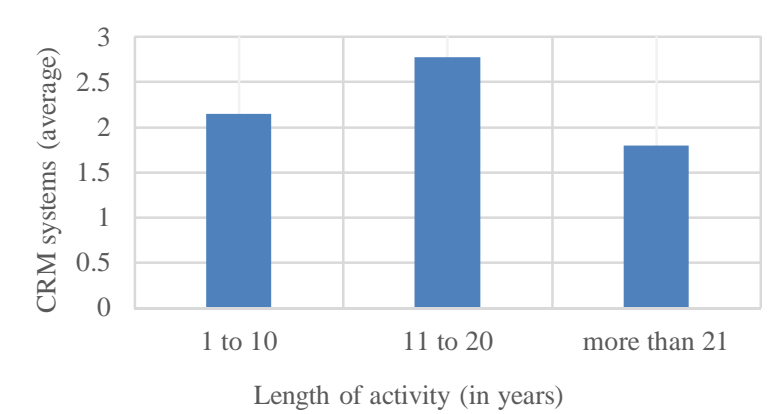

Figure 1 Desired groups

These groups were not normally distributed because their p-values were $0.0025,0.0244,<.001$, respectively. So, the Kruskal-Wallis test to find out statistical relevancy between means of these groups was done. It was calculated $\mathrm{H}$ statistic $=4.3121$ and $\mathrm{p}$ value $=0.1158$ which meant that result was not significant. It could have been considered that between means of each group were not any differences. But the interesting fact was visual and numeric difference between the second and the third column, so we have focused on their means using the Mann-Whitney $U$ test (Table 3).

Table 3 The results of Mann-Whitney $U$ test

\begin{tabular}{|c|c|c|}
\cline { 2 - 3 } \multicolumn{1}{c|}{} & $\begin{array}{c}11 \text { to 20 years old } \\
\text { companies }\end{array}$ & $\begin{array}{c}\text { More than 20 years } \\
\text { old companies }\end{array}$ \\
\hline Sum of ranks & $\mathbf{2 6 8}$ & $\mathbf{2 6 0}$ \\
\hline $\begin{array}{c}\text { Mean of } \\
\text { ranks }\end{array}$ & $\mathbf{2 0 . 6 2}$ & $\mathbf{1 3 . 6 8}$ \\
\hline $\begin{array}{c}\text { Expected } \\
\text { sum of ranks }\end{array}$ & $\mathbf{2 1 4 . 5}$ & $\mathbf{3 1 3 . 5}$ \\
\hline U-value & $\mathbf{7 0}$ & $\mathbf{1 7 7}$ \\
\hline Z-score & $\mathbf{- 2 . 0 3 3 6}$ & \\
\hline p value & $\mathbf{0 . 0 4 2 4}$ & \\
\hline $\begin{array}{c}\text { Expected U- } \\
\text { value }\end{array}$ & $\mathbf{1 2 3 . 5}$ & \\
\hline
\end{tabular}

Hypothesis about equality of means was rejected, so it could be said that companies with length of activity from 11 to 20 years used CRM systems more than companies with length of activity over 20 years. We could see, what the frequency of using CRM systems in each was given year measurement. This dependence could not be fitted by simple curve, probably by some another group of function with more complicated course (Figure 2). 


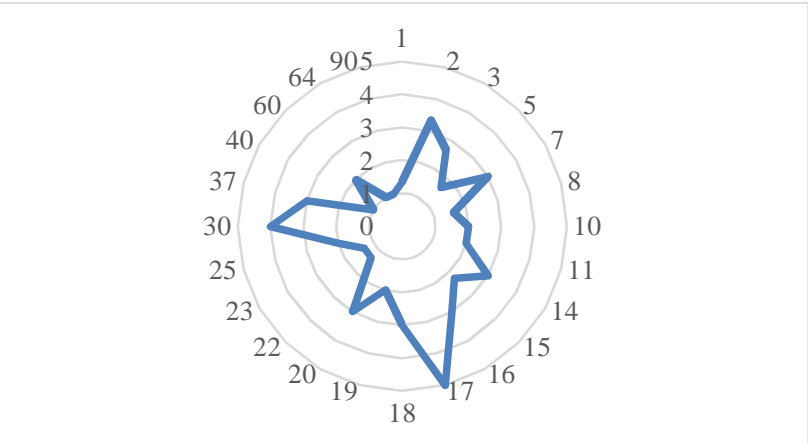

Figure 2 Frequency of using CRM systems

According to fig. 2, older companies use the CRM systems in more rate. That's exploitation rate about value of 5. Values from 1 to 90 represent age of construction companies on the market. Values from 0 to 5 represent impact rate of exploitation of CRM systems. After this quick view, older companies use this tool in more rate than younger construction companies.

Research has highlighted the fact that if we only look at business size dependence and CRM usage, apart from the fact that large firms are one, they also use CRM systems the same way. And if we look at the use of CRM according to the length of market activity (divided into three groups), the statistically significant difference between these groups is not. If we looked at the significance of the differences between the pairs of the columns, we found one importance between the $2^{\text {nd }}$ and the $3^{\text {rd }}$ group. Businesses on the market 11 to 20 years use CRM systems as well as younger companies but significantly more than older companies (over 20 years). We also made a graph to see how many years we are using CRM systems (we see that it is about the $17^{\text {th }}$ year).

\section{Conclusions}

Customer relationships management system are very progressive tool in management of relationships with customers. Use of this systems brings a lot of benefits. From this reason, it is very important to explore this area. This research discussed CRM systems in Slovak construction industry from use of this tool according to company size and length of time on the market point of view. Research didn't confirm assumption about use of CRM system depends on company size. Assumption, bigger companies use CRM systems more than small companies was rejected. Second point of view was more difficult for interpretation results. Research shown some trends and interesting facts about it. Based on, these technologies need to be discussed and explored. Potential for expanded research, it can be explore the impact on results of companies. Next space for research is in other markets (as mentioned Polish construction market and so on).

\section{Acknowledgement}

The paper presents a partial research results of project VEGA 1/0828/17 "Research and application of knowledge-based systems for modeling cost and economic parameters in Building Information Modeling".

\section{References}

[1] ČARNICKÝ, Š., MESÁROŠ, P.: Business Intelligence and Knowledge Management: A Business Perspective, Brussels, EuroScientia vzw, 2013.

[2] KRŠÁK, B., TOBISOVÁ, A., SEHNÁLKOVÁ, M.: Information technologies and their using during firm's financial health modelling, Transactions of the Universities of Košice, Vol. 4, p. 35-40, 2011.

[3] MESÁROŠ, P., MANDIČÁK, T.: Impact of ICT on performance of construction companies in Slovakia, IOP Conference Series: Materials Science and Engineering, WMCAUS 2017, Bristol, IOP Publishing, Vol. 24, p. 1-9, 2017.

[4] MESÁROŠ, P., MANDIČÁK, T.: Impact of information and communication technology on cost management in construction industry - Empirical study, Wambeek, EuroScientia, p. 136, 2017.

[5] MADU, C., N., KUEI. C.: ERP And supply chain management, Faifield, Chi Publishers, 2005.

[6] MESÁROŠ, P., MANDIČÁK, T.: Ekonomické informačné systémy, Košice, Technical university of Košice, Faculty of Civil Engineering, 2017. (Original in Slovak)

[7] ČARNICKÝ, Š., MESÁROŠ, P.: Informačné systémy podnikov, Bratislava, Ekonóm, 2009. (Original in Slovak)

[8] MISHRA, A., MISHRA, D.: Customer Relationship Management: Implementation Process Perspective, Acta Polytechnica Hungarica, Vol. 6, No. 4, p. 83-99, 2009.

[9] LABUS, M., STONE, M.: The CRM behaviour theory - Managing corporate customer relationships in service industries, Journal of Database Marketing \& Customer Strategy Management, Vol. 17, No. 3-4, p. 155-173, 2010. doi:10.1057/dbm.2010.17

[10] KOTLER, P., ARMSTRONG, G.: Marketing, Praha, Grada publishing, 2009. (Original in Czech)

\section{Review process \\ Single-blind peer review process.}

